\title{
PENGEMBANGAN BUKU AJAR BAHASA INGGRIS \\ BERBASIS KURIKULUM 2013
}

\section{Marsuki}

marsukigani@yahoo.com

IKIP Budi Utomo Malang Jawa Timur

\begin{abstract}
The purpose of the study is to describe the need analysis rate of English textbook for secondary school based on the character value within the curriculum 13 . It also identifies the map of the student's knowledge on character based education. The research design is need assessment survey, while the data collection techniques involve questionnaire and deep interview. The sample of the study is 6 secondary schools implementing curriculum 13 in Kabupaten Sumenep. The target subject are 6 English teachers and 130 students of secondary schools. The data analysis shows that 6 secondary schools implementing curriculum 13 at present needed an English textbook based on the character value which can be used as a supplement of the required English book from Kemendikbud. It is expected to facilitate the students study and understand English textbook. Besides, out of 130 students, $92.06 \%$ indicate excellent level of their knowledge and understanding toward nation character and culture values. Nevertheless, 7.94 students have not been able to answer some questions correctly.
\end{abstract}

Keywords: value, character, curriculum

\section{PENDAHULUAN}

Bahasa Inggris sebagai bahasa asing di Indonesia merupakan mata pelajaran wajib yang diajarkan pada siswa SMP baik dalam kurikulum 2013 maupun kurikulum sebelumnya. Sebagai bahasa Internasional dalam era global sekarang ini, bahasa Inggris memiliki peran dan fungsi yang sangat penting sebagai alat komunikasi dan interaksi untuk mengekspresikan pikiran, perasaan, emosi, dan kebutuhan umat manusia dalam kehidupan setiap hari.

Dalam kurikulum 2013 disebutkan bahwa siswa diharapkan dapat memiliki 4 Kompetensi Inti (KI) yaitu kompetensi sikap spiritual, kompetensi sikap sosial, kompetensi pengetahuan, dan kompetensi keterampilan dalam belajar bahasa Inggris. Keempat kompetensi tersebut dijabarkan ke dalam Kompetensi Dasar (KD) yang harus dicapai oleh siswa SMP dalam belajar bahasa Inggris. Misalnya, dalam kompetensi dasar sikap spiritual dinyatakan bahwa siswa SMP harus mensyukuri kesempatan belajar bahasa Inggris sebagai bahasa pengantar komunikasi internasional yang diwujudkan dalam semangat belajar. Sedangkan pada kompetensi dasar sikap sosial diantaranya adalah siswa dapat menunjukkan perilaku santun, jujur, bertanggung jawab, bekerja sama, disiplin, percaya diri, dan cinta damai dalam berkomunikasi bahasa Inggris baik secara interpersonal dan transaksional. Dalam salah satu kompetensi dasar pengetahuan dijelaskan siswa dapat memahami fungsi sosial, struktur teks, dan unsur kebahasaan dari teks dan dapat menyusun. teks lisan sederhana untuk mengucapkan dan merespon sapaan, pamitan, ucapan terima kasih, dan permintaan maaf untuk kompetensi dasar keterampilan (Peraturan Mendikbud, 2013).

Untuk meningkatkan kompetensi pelajaran bahasa Inggris khususnya bagi siswa SMP di Kabupaten Sumenep-Madura, 
berbagai cara tentunya dapat dilakukan misalnya melalui pengembangan buku ajar, metode pembelajaran, materi ajar, media pembelajaran, dan sebagainya yang disesuaikan dengan kurikulum 2013. Dalam penelitian ini, pengembangan buku ajar bahasa Inggris dengan mengintegrasikan nilai-nilai karakter berbasis kurikulum 2013 menjadi topik dan pembahasan utama yang akan dilakukan untuk meningkatkan kompetensi siswa SMP khususnya di kabupaten Sumenep-Madura. Peningkatan kompetensi yang berkarakter bagi siswa SMP melalui pengembangan buku ajar bahasa Inggris merupakan perwujudan dari undangundang nomor 20 tahun 2003 tentang Sistem Pendidikan Nasional. Dinyatakan dengan jelas bahwa pendidikan adalah usaha sadar dan terencana untuk mewujudkan suasana pembelajaran agar peserta didik secara aktif mengembangkan potensi dirinya serta untuk memiliki kekuatan spiritual keagamaan, kecerdasan akhlak mulia serta keterampilan yang diperlukan dirinya (Marsuki, 2013 dan UU Sisdiknas, 2003). Oleh karena itu, Mendiknas Prof. Ir. H. Mohammad Nuh (2009) menegaskan bahwa pendidikan karakter bangsa perlu dimasukkan dalam kebijakan pembangunan pendidikan nasional karena tatakrama, etika, dan kreativitas lulusan dianggap menurun dan menjadi keluhan masyarakat (Marsuki, 2013, h. 6).

Banyak kasus asusila dan kenakalan dewasa ini yang dilakukan oleh siswa-siswa SMP diekspos beragam media baik media elektronik maupun cetak. Misalnya, pada tanggal 30 Maret 2013 terjadi tawuran antar siswa di SMPN 1 Arjasa Kangean Sumenep dan sebagian mereka menggunakan senjata tajam. Kasus-kasus asusila juga terjadi di daerahdaerah lain khususnya yang melibatkan siswa SMP. Hal ini mendasari dirumuskannya kurikulum 2013 berikut standar isi yang meliputi Standar Kompetensi Lulusan (SKL), Kompetensi Inti (KI), dan Standar Kompetensi (SK). Standar tersebut berisikan nilai-nilai karakter seperti beriman, bertakwa, bersyukur, santun, peduli, jujur, disiplin, percaya diri, kerja sama, cinta damai, rasa ingin tahu, cerdas, berilmu, berakhlak mulia, sehat, cakap, kreatif, mandiri, dan menjadi warga negara yang demokratis serta bertanggung jawab (Kemdiknas, 2011).
Untuk mewujudkan model buku ajar bahasa Inggris berbasis nilai-nilai karakter Kurikulum 2013 untuk siswa SMP di Kabupaten Sumenep Madura diperlukan landasan empiris. Penelitian ini bertujuan mendeskripsikan (1) kebutuhan sekolah terhadap pengembangan buku ajar bahasa Inggris berbasis nilai-nilai karakter kurikulum 2013 bagi siswa SMP di Kabupaten SumenepMadura dan (2) peta pengetahuan siswa SMP terhadap nilai-nilai pendidikan karakter yang dapat digunakan untuk mengembangkan buku ajar bahasa Inggris berbasis nilai-nilai karakter kurikulum 2013 di Kabupaten Sumenep-Madura.

\section{PENDAHULUAN \\ Pembelajaran Bahasa Inggris di Indonesia}

Bahasa Inggris sebagai bahasa internasional banyak dipelajari dan diajarkan sebagai bahasa kedua maupun sebagai bahasa asing di dunia termasuk di Indonesia. Fungsi bahasa Inggris dalam konteks globalisasi tidak banyak berubah yaitu sebagai alat yang sangat diperlukan untuk penyerapan ilmu dan teknologi, serta untuk berkomunikasi dengan bangsa lain dalam kerangka hubungan internasional di berbagai aspek kehidupan manusia (Saukah, 2003 dalam Bahasa \& Pembelajaran Bahasa, 2009, h.54).

Mengingat bahasa Inggris sangat penting sebagai bahasa komunikasi global, maka sejak awal kemerdekaan bahasa Inggris telah diberi status sebagai bahasa asing pertama yang wajib diajarkan di sekolah lanjutan (Sadtono, 1997: Huda, 1997 dalam Saukah, 2003). Oleh karena itu, siswa SMP diharapkan dapat memiliki kompetensi yang mumpuni baik kompetensi kebahasaan (grammatical competence) maupun kompetensi komunikatif (communicative competence) sehingga mereka dapat melakukan fungsi bahasa Inggris secara transaksional dan interaksional yang tercermin dalam 3 kompetensi yaitu sikap (spiritual dan sosial), pengetahuan, dan keterampilan (Peraturan Mendikbud, 2013).

\section{Pelajaran Bahasa Inggris dalam Kurikulum 2013}

Dalam Peraturan Mendikbud tentang Kurikulum 2013 dan buku "Materi Pelatihan Guru sebagai Implementasi Kurikulum 2013 dijelaskan tentang pembelajaran bahasa 
Inggris SMP berdasarkan kurikulum 2013. Sebagaimana dijelaskan di atas, pemberlakuan kurikulum 2013 dilakukan secara bertahap dan pembelajaran bahasa Inggris khususnya dimulai dari kelas VII. Dalam kurikulum yang baru ini, Standar Kompetensi Lulusan (SKL) mengikat pada semua mata pelajaran termasuk pelajaran bahasa Inggris. Ini berarti seluruh matapelajaran dalam pengembangannya harus mengacu pada SKL. Sementara SKL dikembangkan berdasarkan kebutuhan peserta didik yang mengutamakan adanya keseimbangan antara kompetensi soft skill dan hard skill (Sutiana, 2013).

Ada tiga kompetensi dalam pembelajaran bahasa Inggris yang harus dicapai dan dikuasai oleh siswa SMP yaitu kompetensi sikap, pengetahuan, dan keterampilan. Kompetensi sikap dijabarkan ke dalam kompetensi spiritual dan kompetensi sosial. Dari jabaran ini secara keseluruhan terdapat empat kompetensi yaitu kompetensi sikap spiritual, sikap sosial, pengetahuan, dan keterampilan (Peraturan Mendikbud, 2013). Keempat kompetensi ini diklasifikasikan ke dalam Kompetensi Inti (KI) yang dijabarkan ke dalam KI-1= Sikap Spiritual, KI-2= Sikap Sosial, KI-3= Pengetahuan, dan KI-4= Keterampilan yang semuanya akan mengikat pada Kompetensi Dasar (KD) untuk semua mata pelajaran.

Untuk wacana kebahasaan yang diajarkan khususnya untuk kelas VII SMP meliputi lima wacana yaitu wacana interpersonal, wacana transaksional, wacana fungsional khusus, wacana fungsional umum, dan topik pembicaraan. Wacana interpersonal adalah wacana yang berisi ungkapanungkapan yang dilakukan dalam berbahasa untuk keakraban dan menjaga solidaritas seperti ungkapan sapaan (greeting), beserta balasannya (response), ungkapan terima kasih (thanking) beserta balasannya, ungkapan minta maaf (apologizing), dan lain-lain. Sedangkan wacana transaksional adalah wacana yang berfungsi untuk mendapatkan informasi, menanyakan fakta-fakta, serta meminta atau menawarkan barang dan jasa.

Sementara wacana fungsional adalah wacana yang mengarah pada penggunaan bahasa dalam kontek kehidupan setiap hari. Wacana ini terdiri dari wacana fungsional khusus dan wacana fungsional umum. Wacana fungsional khusus mengacu pada penggunaan kebahasaan yang berkaitan dengan label nama, list (daftar barang dalam satu kelompok), instruksi, tanda atau rambu, tanda peringatan, dan lagu. Sedangkan wacana fungsional umum mengacu pada nama hari, bulan, nama waktu dalam hari, waktu dalam bentuk angka, tanggal, dan tahun, jati diri, nama binatang, benda dan bangunan publik, sifat orang, binatang, dan benda. Sedangkan topik pembicaraan terkait dengan diri dan lingkungan sosial dan alam di sekitar rumah dan sekolah.

Proses pembelajaran dalam kurikulum 2013 menggunakan pendekatan Scientific, dengan runtutan kegiatan melalui proses: mengamati, mempertanyakan, bereksplorasi/ bereksperimen, mengasosiasi/ menganalisis, dan berkomunikasi (Sutiana, 2013). Untuk melakukan proses tersebut, diperlukan model-model pembelajaran sebagai kegiatan belajar mengajar. Model-model yang menjadi rujukan dalam kurikulum 2013 adalah pembelajaran berbasis proyek (project-based learning), pembelajaran berbasis masalah (problem-based learning), dan pembelajaran penemuan (discovery learning).

\section{Pengetahuan Siswa terhadap Nilai-Nilai Karakter}

Pengetahuan siswa tentang nilai-nilai luhur, budi pekerti, moral dan etika dapat diperoleh dari berbagai sumber misalnya nasehat-nasehat orang tua, guru ataupun teman. Bahkan pemahaman itu juga bersumber dari apa yang dilihat, didengar, dan dibaca seperti televisi, radio, buku, majalah, surat kabar, dan lain-lain. Sebagai anak remaja yang terus tumbuh dan berkembang, siswa SMP perlu mendapat perhatian, perlakuan, dan penanganan yang cukup serius sehingga pola pikir, perilaku, akhlak, moral, dan etika mereka akan menjadi baik. Oleh karena itu, orang tua dan sekolah harus membangun kerja sama yang baik untuk mencapai kesuksesan dalam membangun kognitif, afektif, dan psikomotorik anak atau perserta didiknya.

Dalam pengembangan buku ajar berbasis nilai-nilai karakter, perlu adanya survey tentang seberapa jauh pemahaman dan pengetahuan siswa terhadap nilai-nilai luhur tersebut. Hal ini dilakukan sebagai pedoman serta barometer dalam penyusunan buku ajar bahasa Inggris. Penelitian yang telah 
dilakukan terkait survey di level SD di kota Malang. Hasilnya menunjukkan bahwa 194 $(96,42 \%)$ dari 200 siswa memiliki tingkat pemahaman dan pengetahuan yang sangat baik terhadap nilai-nilai budaya dan karakter bangsa Indonesia. Sebaliknya, 6 siswa atau $3,68 \%$ siswa belum bisa menjawab angket dengan benar (Marsuki, 2013).

\section{Nilai-Nilai Karakter Bangsa}

Kandungan nilai-nilai pembentuk karakter ini tercermin dan terwujud dalam kurikulum 2013 melalui Standar Kompetensi Lulusan (SKL), Kompetensi Inti (KI) dan Standar Kompetensi (SK). Ini berarti bahwa nilai-nilai karakter dalam kurikulum 2013 didasarkan pada nilai-nilai karakter pada dua buku 'Pengembangan Pendidikan Budaya dan Karakter Bangsa' tahun 2010 dan 'Panduan Pelaksanaan Pendidikan Karakter' tahun 2011 yang akan diintegrasikan melalui pengembangan buku ajar bahasa Inggris untuk meningkatkan kompetensi siswa SMP Kabupaten Sumenep-Madura. Nilai-nilai tersebut didasarkan pada pada (1) agama, (2) Pancasila, (3) budaya nasional, dan (4) tujuan pendidikan nasional (Kemdiknas, 2010 dalam Marsuki, 2013). Dalam buku tersebut dijelaskan tentang nilai-nilai karakter yang berjumlah 18 unsur yaitu (1) religius, (2) jujur, (3) toleransi, (4) disiplin, (5) kerja keras, (6) kreatif, (7) mandiri, (8) demokratis, (9) rasa ingin tahu, (10) semangat kebangsaan, (11) cinta tanah air, (12) menghargai prestasi, (13) bersahabat atau komunikatif, (14) cinta damai, (15) gemar membaca, (16) peduli lingkungan, (17) peduli sosial, dan (18) tanggung jawab.

Selain itu, nilai-nilai karakter tersebut dikembangkan dan diklasifikasikan ke dalam empat olah yaitu (1) olah pikir yang terdiri dari nilai-nilai cerdas, kritis, kreatif, inovatif, ingin tahu, berpikir terbuka, produktif, berorientasi Ipteks, dan reflektif, (2) olah raga yang terdiri dari nilai-nilai bersih dan sehat, disiplin, sportif, tangguh, andal, berdaya tahan, bersahabat, kooperatif, determinatif, kompetitif, ceria, dan gigih, (3) olah hati yang terdiri dari nilai-nilai beriman dan bertakwa, jujur, amanah, adil, bertanggung jawab, berempati, berani mengambil resiko, pantang menyerah, rela berkorban, dan berjiwa patriotik, dan (4) olah rasa/karsa yang terdiri dari nilai-nilai ramah, saling menghargai, toleran, peduli, suka menolong, gotong royong, nasionalis, kosmopolit, mengutamakan kepentingan umum, bangga menggunakan bahasa dan produk Indonesia, dinamis, kerja keras, dan beretos kerja.

\section{METODE}

Penelitian ini menggunakan rancangan penelitian survey tingkat kebutuhan sekolah pada pengembangan buku ajar bahasa Inggris berbasis nilai-nilai karakter kurikulum 2013. Selain itu, survey tersebut juga mengukur peta pengetahuan siswa SMP terhadap nilai-nilai pendidikan karakter. Hasil survey dapat digunakan untuk pengembangan buku ajar bahasa Inggris berbasis nilai-nilai karakter kurikulum 2013 di Kabupaten SumenepMadura.

Populasi penelitian ini adalah 76 SMP yang tersebar di 27 Kecamatan di Kabupaten Sumenep-Madura. Berdasarkan kajian awal, hanya ada 6 SMP yang melakukan implementasi Kurikulum 2013 sebagai pilot project yaitu (1) SMPN 1, (2) SMPN 2, (3) SMPN 4, (4) SMPN 1 Kalianget, (5) SMPN 1 Saronggi, dan (6) SMPN Talango Sumenep. Sedangkan instrumen penelitian untuk mengumpulkan data dalam penelitian ini adalah angket dan wawancara. Angket dan wawancara ini digunakan untuk mendapatkan informasi dan deskripsi tentang (1) tingkat kebutuhan sekolah pada pengembangan buku ajar bahasa Inggris, (2) peta pengetahuan siswa SMP terhadap nilai-nilai pendidikan nilai-nilai karakter. Data yang terkumpul selanjutnya dianalisis secara kuantitatif dan kualitatif.

\section{HASIL PENELITIAN}

Berikut ini dipaparkan hasil analisis data sebagai temuan penelitian yang meliputi dua aspek utama yaitu tingkat kebutuhan sekolah pada pengembangan buku ajar bahasa Inggris dan peta pengetahuan siswa SMP terhadap nilai-nilai pendidikan karakter.

\section{Tingkat Kebutuhan Sekolah Terhadap Buku Ajar Bahasa Inggris}

Berdasarkan analisis data yang berupa wawancara dengan 6 guru bahasa Inggris ditemukan bahwa sekolah sangat membutuhkan pengembangan buku ajar bahasa Inggris berbasis nilai-nilai budaya dan karakter bangsa. Dengan demikian buku ajar 
tersebut harus berisi komponen kemampuan dan keterampilan yang dapat diintegrasikan dengan nilai-nilai budaya dan karakter bangsa berdasarkan Pancasila, UUD 1945, norma agama, sistem pendidikan nasional dan budaya bangsa.

Berdasarkan hasil survei, buku ajar untuk mata pelajaran bahasa Inggris yang digunakan hanyalah 1 buku dari Kemendikbud yang berjudul 'When The Bell Rings'. Suplemen buku lainnya kurang memadai dalam menunjang proses belajar mengajar siswa. Dalam Kurikulum 2013, guru dan murid sangat diharapkan bisa kreatif dan aktif untuk menciptakan suasana pembelajaran yang kondusif. Misalnya dengan mencari tambahan materi dan sumber belajar lainnya baik melalui buku-buku, media cetak ataupun elektronik, media internet dan sebagainya. Buku ajar Bahasa Inggris yang digunakan oleh sekolah pada saat ini memuat banyak materi ajar berupa contoh-contoh dan gambar dalam kemampuan kebahasaan dan keterampilan dengan penjelasan yang singkat sebagai pengembangan mandiri diri siswa. Buku wajib tersebut sangat sulit bagi siswa sehingga tidak semua sekolah siap melaksanakan sistem dan pola pembelajaran tersebut. Ini tentu dikarenakan faktor teknis maupun non-teknis.

Secara teknis, siswa pada umumnya belum siap dituntut kreatif dan mandiri untuk mencari sumber belajar sendiri selain dari guru. Misalnya, mereka harus mencari dan mengakses materi-materi penunjang pembelajaran mereka di internet. Selain itu, banyak sekolah yang masih tidak memfasilitasi lingkungan sekolahnya dengan hotspot. Bahkan guru selalu mencari materi tambahan dalam bentuk lembar kopian yang dibagikan kepada semua siswa dengan tujuan mereka dapat memahami materi pembelajaran bahasa Inggris sesuai dengan tujuan pembelajaran yang telah digariskan dalam Kompetensi Inti (KI) dan Kompetensi Dasar (KD) sebagai indikator pencapaian.

Sedangkan faktor non-teknis adalah faktor ekonomi yang tentu saja mempengaruhi semangat belajar siswa pada materi yang selalu dikaitkan dengan maju dan pesatnya ilmu pengetahuan dan teknologi informasi. Fakta ini menjadi kendala karena adanya kesenjangan antara harapan dan kenyataan. Namun demikian, hanya ada 2 SMP yang betul-betul siap menjadi pilot project implementasi Kurikulum 2013 yaitu SMPN 1 dan SMPN 2 Sumenep. 2 sekolah ini selain sudah lama berpengalaman menyelenggarakan proses pembelajaran di Kota Sumenep, juga didukung dengan fasilitas yang memadai untuk meningkatkan prestasi belajar bahasa Inggris siswanya. Apalagi terdapat kelas-kelas unggulan yang dikelompokkan dengan maksimal hanya 20 sampai 25 siswa. Kebanyakan mereka juga didukung dengan ekonomi orang tua yang mampu sehingga siswa tersebut dapat membeli buku-buku suplemen dan mengakses internet sebagai sumber belajar untuk mendukung proses belajarnya. Sementara sekolah-sekolah lainnya seperti SMPN 4, SMPN 1 Kalianget, SMPN Saronggi 1, dan SMP Talango membutuhkan waktu yang lebih guna memenuhi tuntutan Kurikulum 13. Semua guru khususnya guru Bahasa Inggris memiliki kualifikasi dan kemampuan yang tidak jauh berbeda di 6 SMP tersebut di Kabupaten Sumenep.

\section{Peta Pengetahuan Siswa SMP Terhadap Nilai-Nilai Pendidikan Karakter}

Berdasarkan hasil analisis dari angket 130 siswa di 6 SMP yang mengimplementasikan kurikulum 2013 di Kabupaten Sumenep ditemukan bahwa pemahaman siswa terhadap nilai-nilai budaya dan karakter bangsa dapat ditunjukkan secara rinci melalui rekapan dalam Tabel 1.

Table 1. Respon angket pemahaman nilai-nilai karakter

\begin{tabular}{ccc}
\hline Nomor Soal & \multicolumn{2}{c}{ Prosentase } \\
\cline { 2 - 3 } & Jawaban Benar & Jawaban Salah \\
\hline 1. & $99,23 \%$ & $0,77 \%$ \\
2. & $99,23 \%$ & $0,77 \%$ \\
3. & $94,62 \%$ & $5,38 \%$ \\
4. & $90,75 \%$ & $9,25 \%$ \\
5. & $98,45 \%$ & $1,55 \%$ \\
6. & $93,08 \%$ & $6,92 \%$ \\
7. & $92,31 \%$ & $7,69 \%$ \\
8. & $85,39 \%$ & $14,61 \%$ \\
9. & $98,45 \%$ & $1,55 \%$ \\
10. & $93,08 \%$ & $6,92 \%$ \\
11. & $97,69 \%$ & $2,31 \%$ \\
12. & $98,45 \%$ & $1,55 \%$ \\
13. & $81,54 \%$ & $18,54 \%$ \\
14. & $99,23 \%$ & $0,77 \%$ \\
15. & $50,77 \%$ & $49,23 \%$ \\
16. & $89,23 \%$ & $10,77 \%$ \\
17. & $96,92 \%$ & $3.08 \%$
\end{tabular}




\begin{tabular}{lcc}
18. & $69,23 \%$ & $30,77 \%$ \\
19. & $84,62 \%$ & $15,38 \%$ \\
20. & $89,23 \%$ & $10,77 \%$ \\
21. & $95,39 \%$ & $4,61 \%$ \\
22. & $99,23 \%$ & $0,77 \%$ \\
23. & $99,23 \%$ & $0,77 \%$ \\
24. & $97,69 \%$ & $2,31 \%$ \\
25. & $96,15 \%$ & $3,85 \%$ \\
26. & $92,31 \%$ & 7,69 \\
27. & $93,85 \%$ & $6,15 \%$ \\
28. & $100 \%$ & $0 \%$ \\
29. & $89,23 \%$ & $10,77 \%$ \\
30. & $92,31 \%$ & 7,69 \\
31. & $96,92 \%$ & $3,08 \%$ \\
32. & $80,77 \%$ & $19.23 \%$ \\
33. & $90 \%$ & $10 \%$ \\
34. & $90 \%$ & $10 \%$ \\
35. & $86,15 \%$ & $13,85 \%$ \\
36. & $95,39 \%$ & $4,61 \%$ \\
37. & $92,31 \%$ & $7,69 \%$ \\
38. & $96,92 \%$ & $3,08 \%$ \\
39. & $99,23 \%$ & $0,77 \%$ \\
40. & $97,69 \%$ & $2,31 \%$ \\
\hline
\end{tabular}

Dari paparan tabel 1. di atas dapat disimpulkan bahwa 92,06\% dari 130 siswa menunjukkan tingkat pemahaman dan pengetahuan yang sangat baik terhadap nilainilai luhur bangsa. 7,94\%, siswa belum bisa menjawab beberapa pertanyaan dengan benar. Kesalahan yang paling banyak ditemukan pada soal nomor 15 (49,23\%), nomor 18 (30,77\%), nomor 32 (19,23\%), nomor $13(18,54 \%)$, nomor $8(14,63 \%)$, dan nomor 35 (13,85\%).

Hasil temuan di atas menunjukkan bahwa siswa memiliki pengetahauan dan pemahaman yang sangat baik terhadap nilainilai budaya dan karakter bangsanya sendiri. Maka, potensi dan kompetensi tersebut diharapkan terus terwujud. Dalam pembangunan mental generasi penerus bangsa, perlu pengintegrasian nilai-nilai budaya dan karakter bangsa pada mata pelajaran termasuk bahasa Inggris. Dus, siswa akan dapat mengembangkan watak serta peradaban bangsa yang bermartabat, beriman dan bertakwa kepada Tuhan Yang Maha Esa, berakhlak mulia, sehat, berilmu, cakap, kreatif, mandiri, dan menjadi menjadi manusia seutuhnya.

\section{PEMBAHASAN}

Paparan hasil temuan tentang tingkat kebutuhan sekolah terhadap buku ajar bahasa Inggris dan peta pengetahuan siswa SMP di
Kabupaten Sumenep terhadap nilai-nilai pendidikan karakter di atas akan dibahas di bawah ini:

\section{Tingkat Kebutuhan Sekolah Terhadap Buku Ajar Bahasa Inggris}

Berdasarkan temuan dinyatakan bahwa semua guru bahasa Inggris membutuhkan pengembangan buku ajar bahasa Inggris berbasis nilai-nilai budaya dan karakter bangsa. Buku tersebut dapat dijadikan suplemen untuk menunjang penggunaan buku wajib dari Kemendikbud yang berjudul 'When The Bell Rings'.

Dibutuhkannya buku tersebut dilandasai beberapa alasan mendasar. Pertama, nilai-nilai budaya dan karakter bangsa sangat dibutuhkan untuk ditransfer pada generasi penerus bangsa khususnya siswa-siswa SMP mengingat nilai-nilai tersebut mengalami degradasi. Dengan integrasi nilai-nilai tersebut pada kurikulum, silabus, dan buku ajar khususnya bahasa Inggris, maka siswa dapat memperoleh transfer nilai (transfer of value) selain transfer pengetahuan (transfer of knowledge) dalam proses pembelajarannya (Supina \& Parmi, 2011, Sunarti, 2012). Tugas guru tidak hanya mengajar tetapi mendidik untuk membangun karakter (character building) dan budi pekerti, akhlak, serta pengetahuan para siswanya agar menjadi siswa yang cerdas dan cemerlang sekaligus berhati mulya berdasarkan nilai-nilai budaya dan karakter bangsa. Kedua, diperlukan adanya buku ajar yang bisa menjembatani bagi siswa yang mengalami kesulitan dalam memahami buku pegangan wajib dari Kemendikbud.

Berdasarkan uraian di atas, dapat disimpulkan bahwa nilai-nilai budaya dan karakter bangsa sebagai amanah dari Pancasila dan UUD 1945 harus diintegrasikan melalui pengembangan buku ajar Bahasa Inggris. Ini bertujuan untuk mengatasi permasalahan seperti disorientasi dan belum dipahaminya nilai-nilai Pancasila dan keterbatasan perangkat kebijakan terpadu dalam mewujudkan nilai-nilai Pancasila. Selain itu untuk mencegah bergesernya nilainilai etika dalam berbangsa dan bernegara, memudarnya kesadaran dalam nilai-nilai budaya bangsa, ancaman disintegrasi bangsa, dan melemahnya kemandirian bangsa (Supina \& Parmi, 2011). Oleh karena itu pembangunan 
karakter melalui pendidikan budaya dan karakter bangsa menjadi salah satu progam prioritas pembangunan nasional yang tertuang dalam Rencana Pembangunan Jangka Panjang Nasional (RPJPN) dalam tahun 20052025.

\section{Peta Pengetahuan Siswa SMP Terhadap Nilai-Nilai Pendidikan Karakter}

Temuan penelitian ini menunjukkan 92,06\% siswa SMP di Kabupaten Sumenep menunjukkan tingkat pemahaman dan pengetahuan yang sangat baik terhadap nilainilai luhur bangsa. Peta pemahaman pengetahuan tersebut didasarkan pada 18 nilai-nilai karakter yang dipaparkan pada buku "Pengembangan Pendidikan Budaya dan Karakter Bangsa" tahun 2010.

Nilai-nilai karakter mencerminkan cara berpikir, bertindak, dan berperilaku anak bangsa sesuai dengan budaya dan karakter bangsa. Pemahaman dan pengetahuan siswa SMP tentang nilai-nilai budaya dan karakter bangsa menunjukkan bahwa mereka secara meyakinkan dapat membedakan mana perilaku-perilaku yang religious, luhur, dan mulya dan mana yang tidak. Oleh karena itu, semua fakta ini akan menjadi data yang sangat berharga dalam pengembangan buku ajar bahasa Inggris interaktif berbasis nilai-nilai budaya dan karakter bangsa. Saat ini, nilainilai afektif yang mencerminkan budaya dan karakter bangsa yang dimiliki khususnya siswa SMP sedang mengalami krisis. Hal inilah harus cepat diatasi dengan langkah yang tepat, diantaranya dengan pengembangan kurikulum dan silabus serta buku ajar berbasis nilai-nilai budaya dan karakter bangsa (Marsuki, 2013).

Hasil penelitian ini telah menemukan bahwa siswa-siswa SMP masih memiliki pemahaman dan pengetahuan yang baik tentang nilai-nilai pendidikan budaya dan karakter bangsa yang digali dari agama, Pancasila, nilai-nilai budaya, dan tujuan pendidikan nasional. Maka, untuk menjaga kesinambungan ini, pemerintah dan masyarakat harus menyelamatkan generasigenerasi penerus bangsa agar menjadi generasi emas yang bisa memikul amanah dan tugas dalam mengantarkan Negara Indonesia menjadi negara bermartabat, cerdas, religius, kreatif, inovatif, dan berakhlakul karimah yang menjadi harga mati sebagai tujuan pendidikan nasional.

\section{SIMPULAN}

Tingkat kebutuhan buku ajar mata pelajaran bahasa Inggris di Kabupaten Sumenep sangat tinggi mengingat bahwa saat ini yang digunakan hanyalah 1 buku dari Kemendikbud yang berjudul 'When The Bell Rings. Bahan ajar Bahasa Inggris yang digunakan oleh sekolah pada saat ini memuat materi berupa contoh-contoh singkat dan gambar penjelasan yang ringkas. Karena itu, suplemen buku penunjang lainnya masih kurang memadai dalam menunjang proses belajar mengajar siswa. Dalam hal ini, siswa memiliki pengetahauan dan pemahaman yang sangat baik terhadap nilai-nilai budaya dan karakter bangsanya sendiri. Ini ditunjukkan dari hasil analisis jawaban mereka tentang nilai-nilai luhur yang berupa nilai-nilai budaya dan karakter yang berjumlah 18 nilai. 92,06\% siswa menunjukkan tingkat pemahaman dan pengetahuan mereka yang sangat baik terhadap nilai-nilai luhur bangsa yaitu nilainilai budaya dan karakter yang dimiliki oleh bangsa Indonesia. Sedangkan 7,94\%, siswa belum bisa menjawab beberapa pertanyaan angket dengan benar.

\section{DAFTAR PUSTAKA}

Bahasa dan Pembelajaran Bahasa. (2009). Kumpulan Pidato Pengukuhan Guru Besar Universitas Negeri Malang. Jilid II. Malang. Penerbit Universitas Negeri Malang.

Kementerian Pendidikan Nasional. (2010). Pengembangan Pendidikan Budaya Karakter Bangsa. Badan Penelitian Pengembangan Pusat Kurikulum. Kemendiknas

Kementerian Pendidikan Nasional. (2011). Panduan Pelaksanaan Pendidikan Karakter. Badan Penelitian dan Pengembangan Pusat Kurikulum dan Perbukuan. Kemendiknas 
Marsuki, Y., \& Efendy, B.A. (2013). Peningkatan Karakter Siswa Sekolah Dasar (SD) Melalui Pengembangan Buku Ajar Bahasa Inggris Interaktif Berbasis Nilai-Nilai Budaya Bangsa di Kota Malang. Penelitian Desentralisasi Hibah Bersaing. Dikti Kemendikbud.

Nuh, M. (2009). Pendidikan Budaya Karakter. Jakarta. Balitbang. Kemendiknas

Peraturan Menteri Pendidikan Nasional (2013) No. 65, 66, 67, 68, 69, 70, 71 tentang Kurikulum 2013. Jakarta: Depdikbud.

Saukah, A. (2003). Pengajaran Bahasa Inggris di Indonesia: Tinjauan Terhadap Unjuk Kerja Pembelajar serta Upaya Peningkatannya. Pidato Pengukuhan Jabatan Guru Besar Bidang Ilmu Pendidikan Bahasa Inggris Pada Fakultas Satra disampaikan dalam Sidang Terbuka Senat Universitas Negeri Malang 3 Maret 2003. Penerbit Universitas Negeri Malang.

Supina \& Parmi, I. T. (2011). Pengembangan Pendidikan Budaya dan Karakter Bangsa melalui Pembelajaran Matematika di SD. Badan Pengembangan Sumber daya Manusia Pendidikan dan Penjaminan Mutu Pendidikan. Kementerian Pendidikan Nasional.

Sutiana, A. (2013). Pembelajaran Bahasa Inggris SMP berdasarkan Kurikulum 2013. LPMP Propinsi Jawa Barat.

Undang-undang Republik Indonesia No. 20 Tahun 2003 Tentang Sistem Pendidikan Nasional. Bandung: Citra Umbara 